\title{
Junior High School Students' Reasoning
}

\author{
Putri Dea Renocha \\ Biology Education Department \\ Indonesia University Of Education \\ Bandung, Indonesia \\ dea.renocha@gmail.com
}

\author{
Diana Rochintaniawati \\ International Program Science Education \\ Indonesia University Of Education \\ Bandung, Indonesia \\ rochintaniawati@gmail.com
}

\author{
Ari Widodo \\ Biology Education Department \\ Indonesia University Of Education \\ Bandung, Indonesia \\ widodo@upi.edu
}

\begin{abstract}
This research aims toidentify at the argument of students reasoning between the group trained with reasoning and withouttraining. The method used was quasi-experiment. With the sampling technique by the cluster random sampling. Total sample of 33 students in experimental group and 33 students control group were chosen by random cluster sampling. The reasoning item test was used as an instrument which isassociated by the biological concepts. The reasoning item test is wasmodifiedbased on Toulmin Argumentation Patterns (TAP) which consisted of claim, data, warrant, backing, qualifier, rebuttal. The results showed the completeness argumentation component of students who got trained at level $1(0.51 \%)$, level 2 $(78.79 \%)$, level $3(16.67 \%)$, level $4(3.03 \%)$. While the students without reasoning training at level $1(4.55 \%)$, level $2(93.43 \%)$, level $3(2.53 \%)$, level $3(3.03 \%)$.
\end{abstract}

\section{Keywords-Component Argumentation; Reasoning}

\section{INTRODUCTION}

Reasoning is the application in the context of problem solving, which involves the relationship between ideas invitation evidence [24]. Reasoning is the process of thinking logically [22] and the conclusions that have been propose by Wason\& Johnson-Laird in Lee \&She[17]. Reasoning is required for all activities of higher-level thinking when completing a task which consisted of analytical, evaluative and creative [4]. Reasoning is used to combine the arguments of the two parts of the claim and the evidence [12].

The results showed that students have difficulty in evidence activities, problem solving that require reasoning generalization and find relationships between data or facts were given [15]. This is because the reasoning ability of students tend to undeveloped and poor([11], [18], [13], [16]). Students reasoning skills did not automatically show up but it need trained and developed. In harmony with that expressed by Brookhart [4], reasoning ability can be trained and developed in schools in the process of learning activities with a variety of strategies, approaches, and methods developed by the teacher. Students reasoning skill can be identified through argumentation. When students give reasoning they obtain and evaluate the reasons which would strengthened their argument to convince others. Students must reveal strong evidence that his argument can be accepted. Bekiroglu \& Eskin[1] stated students reasoning can be when they do debating. As at the time of the discussion, the students may have the same or different reasons with others. The argued that there should be a accompanied by evidence that they have, so that rationality of science were discovered in the ability to establish a convincing argument that invites and theoretical explanation of the data of observation [28]

Argumentation in science learning is needed to build a strong foundation in understanding a concept. During this time the teacher is not using argumentation in science learning. Berland[2] revealed that teachers give students chance to practice the ability argument has helped students to understand how and why scientists build, create and interpret scientific arguments. This makes students must learn complex skills and strategies to use traditional identifying evidence rather than memorizing facts and content. In harmony with that expressed by Nichols, Gillies \& Hedberg[19], teachers who apply the teaching method of collaborative inquiry by the representative was able to make the students improve their understanding of the concept, the ability to interpret and explain the causes ability students into developing arguments. Obsorn \& Patternson, 2011 in Nichols, Gillies \& Hedberg[19] also revealed that engage students in arguing can help students build knowledge. This is because students will strive to develop high-level thinking skills and reasoning. Therefore, argued habituation in learning can determine the ability of students the argue.

Research on the structure of the argument often refers to the framework Toulmin. As mentioned by Verheij [26] that Toulmin's frame work analysed arguments can be used to analyse arguments in much richer ways compare to traditional traditional ways. So Toulmin offer argumentation scheme consisting of six components, That claim, data, warrant, backing, qualifiers and rebuttal, which is also known as Toulmin Argumentation Pattern (TAP). Roshayanti [21] states that the framework mechanism TAP is to analyze differences in function of a sentence that establishes an argument. As summarized the opinion Sampson (2008), based on this framework is seen a strong argument when it contains six components of the [21]. (1) Data, data is synonymous with the 
evidence, which is defined as facts or conditions that are objectively observable, beliefs, or premise that is accepted as true by the audience, or the conclusions that have previously been constructed [12]. Data that is composed of facts or evidence serves as the basis to support the claim [26][23]. (2) Claim, a statement containing structure and is shown as a result (outcome) argument [23]. In other words, the claim is made up of opinions expressed or the desired conclusion debater to be accepted [12]. (3) Warrant, express the reasoning used to communicate data to the claim. According to Toulmin [12], if the data to answer the question, "What information do you have to get to a conclusion?", Then warrants answer the question, "how do you understand from this data?". Warrant may be the expression used as a rule, principle, or licenseinference that acts as a bridge between data and claim. Warrant indicates the relevance of the data to the claim [23]. (4) Backing, an assumption that support a search warrant, can be factual information (such as the observations made in the past), or principles, values or beliefs of the social, environmental organizations, or experience as an individual [23]. Backing composed of facts or reasoning further used to support or legalize the principles contained in the warrant [12]. (5) Qualifier, is simply described as a type of capital operator a statement. Thus, Toulmin qualifier can be considered as part of the statement that expresses a claim supported by the data [26]. Another explanation [12] mentions that the qualifier is an adverb phrase (adverbial phrase) that modifies claim and indicate the power of rational debater against the claim. (6) Rebuttal, involving exception conditions for the argument. The reasons are against the statement can be seen as a kind of rebuttal an argument that is made up warrant, data, and claim [26]. Another term rebuttal in Toulmin structures that reservation, which means an exception to that rule is expressed in the warrant, so this reservation stating conditions that undermine the argument [12]

As summarized the opinion (American Association for the Advancement of Science, (1993); National Research Council, (1996), The student's ability in making reasoning based on the evidence and further participating in scientific arguments also been considered as the main objective of the improvement of science education [9]. Improvement of education involves the development of thinking, reasoning, and problem-solving skills to prepare students to participate in making and evaluating knowledge claims, explanation, model, and design a scientific experiment [6]. As summarized the opinion Varma et al (2011), in some countries like the United States, the development of the ability to reason scientifically has long been a major goal in education, especially for math and science. To support scientific reasoning the involvement and the activities undertaken by teachers should consider the content taught and the cognitive abilities of learners as well as the assessment [25]. Thus, the planned learning activities teachers can stimulate students to scientific reason. It also looks as an efforts to improve education in Indonesia through 2013 curriculum that emphasizes the process of thinking and learning experiences of students acquiring scientific concepts, so that the educational paradigm that focuses learning on the teacher or the teacher as a source of knowledge is now slowly shifting. Teachers are required to be more creative to create a learning environment and activities that can facilitate students to develop the skills of thinking, including reasoning skills.

Based on the above problems then do research was carried out to train the ability of students for reasoning the training of students argumentation which will be measured by the completeness of students argumentation based on Toumin Argumentation Pattern (TAP).

\section{RESEARCH METHODOLOGY}

The method used in this study is quasi-experimental, Research design was adapted from Frankel, 2012 of which there are two groups, i.e. experimental group and control group. The experimental group was given a training while the control group did not receive any training.

Participants of this studyare 33 students for experiment class and 33 students of control class from $7^{\text {th }}$ graders students in one of Junior High School in Bandung. Students were chosen by cluster random sampling technique. Students ability from both class are relatively equal.

Data were collected after the reasoning training students are given for 6 sessions, each session is 3 hour lesson. Instruments used in the form of reasoning problems associated with biological concepts studied by students. Problem reasoning used to see to what extent the completeness of the argument component students. Completeness of student argumentation component based on patterns of argumentation Toulmin (TAP), which consists of a claim, data, warrant, backing, qualifier and rebuttal. Rubric Component argument comes from [5] which has been adapted by [10], in which the level of argumentation consists of Level 1 (only include a claim), level 2 (includes the claims, data, and / or warrant), level 3 (includes the claims, data, warrants, and backing / qualifier / rebuttal), level 4 (includes a claim, data, warrant, backing, and qualifier / rebuttal), level 5 (includes a claim, data, warrant, backing, qualifier and rebuttal ).

\section{RESULT AND DISCUSSION}

A complete argumentation of students in class by reason of training and classes that are not trained to reason:

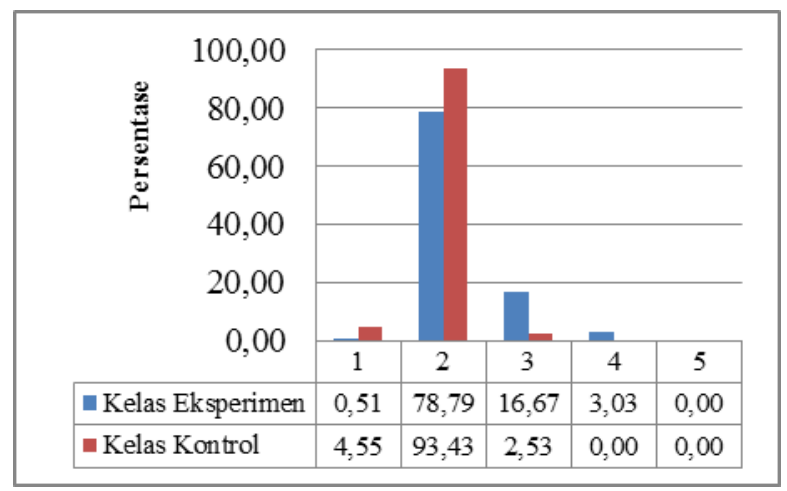

Fig. 1. Students percentage on each level

Fig 1 indicates that completeness of component argument by students without reasoning training is higher in level 1 and 2 (4.55\% level 1; 93.43\% level 2) compared with students in a 
class argument by student who got reasoning training $(0.51 \%$ level $1 ; 78.79 \%$ level 2). Which at level 2 students are able to make a claim that include data and / or warrants. As at the time the students are faced with the statement "all animals that have a backbone classified into vertebrates. Compared with invertebrates, vertebrates have a body composition and body parts more complete ", students argue" Yes, vertebrates have a complete body which has organs that good and perfect (Claim) because when I cut the chicken, I saw no back bones (warrant) ". Arguments other students such as "Yes, vertebrates have a good body composition that makes it stand upright (claim), I've stroked the cat's back and I feel he has a spine (warrant). As said by [12] there are three components that are important in arguing that claim, data and warrant. At level 3 and 4 that a higher percentage of students in a class argument by reasoning training (level $316.67 \% ; 3.03 \%$ level 4 ) as compared with the arguments of students in the class without reasoning training. Argument means students in the class who were given training contain more reasoned claim, data, warrants, and backing / qualifier / rebuttal argument compared with students in handson learning. As in the example case of students in the learning of reasoning follows: "Yes, vertebrate animal has a body composition is complete. (Claim), Structure of the vertebrate body's own bone, organs, and locomotor (warrant), When eating fish, I find the spine I also touched the back of a cat in it there is something hard. I concluded it was spine. (Backing), but in general these invertebrates protected by other body parts. (Rebuttal) ". The argument is an argument that contains five components grouped at level 4. Most students simply file a claim with the data and / or warrant no components other arguments. Students have not been able to supplement his argument by backing, qualifier and rebuttal. Seen in Figure 1 that none of the students in the learning reasoned argument $(0 \%)$ and on the direct instruction $(0 \%)$ who are at level 5 (containing all components of the argument).

In observation of classes by students who got reasoning training used to solve a problem given by the teacher and the teacher asked the reason and evidence that the students were able to put forward arguments along with the reasons and evidence. Each grounds and evidence submitted by the student, the teacher with questions or concerns spontaneous return or feed that must be solved by the students. Habits teachers ask for reasons and evidence can make the students accustomed to the reasons and give evidence in an argument. At the time of the teacher learning also provides tangible evidence directly to students through observation. As in the moss plant material and nails, students were asked by the teacher to observe a variety of plants in front of him, then students are asked to explain what the characteristics of each plant. Then students discuss and put forward the reasons and provide the proof. Discussions were held both in study groups and class discussions involving all students can improve students' reasoning [20]. So that students in the class who got reasoning training had a higher percentage than the classes that are without reasoning training. Shown in Figure 1. Students in the class are given a higher reasoning training at level $3(16.67 \%)$ and $4(3.03 \%)$.

There is ample evidence that students often had difficulty in making and justifying arguments and scientific claims because of the knowledge and the level of their cognitive development is not enough [27], so that the participation of students in discussions argumentative role is to enhance conceptual understanding of the subject matter in school age children, so is the case in the student [14]. There is ample evidence that students often had difficulty in making and justifying arguments and scientific claims because of the knowledge and the level of their cognitive development is not enough [28], so that the participation of students in discussions argumentative role is to enhance conceptual understanding of the subject matter in school age children, so is the case in the student [14]. Some research suggests that activities arguments which students express his views, presenting reasons and evidence to support his view or refute the views of others, it can stimulate the formation of students' knowledge in the classroom [1]. Importance of learning activities to students through argumentation reasoning ability was also expressed by Varma et al. [25] that the habit to disclose evidence, reason, and the other supporting a correct and logical can be trained especially during the learning activity, so that a teacher should be able to consider the type of activity and also the cognitive ability of learners to support the reasoning.

In observation of classes without reasoning training teachers give problems to students but rarely asks questions and asked for proof of the reasons given student. Teachers simply ask students to discuss with classmates and sometimes teachers ask students to make observations to find evidence to support their answers. Only a few students were given reasons and provide evidence and there are some students who could not provide proof of the reason they gave. Although students are not accustomed to in the reasons and evidence that strong but in the class who were not given the training on reasoning shown in Figure 1.there is still an argument students $(4.55 \%)$, which are composed of claims and arguments of students (93.43\%) were claim only equipped with data and / or warrants without any other supporting components. Students are in the habit of not asking the reason teachers and students are not able to lead evidence to argue. The inability of students in arguing that full due classroom learning is still centered on the lack of teachers and learning activities that emphasize the process of argumentation to stimulate students' reasoning ability. It is seen teachers sometimes give problems to be solved and they seldom ask for evidence as they provide answers. This indicates that students are not often involved in the activities of the argument. In fact, an individual involved in the argument will make a reasonable explanation of a phenomenon, expressed their understanding, and to persuade others to accept the idea [2]. Although students rarely do this [2], but the learning activities argumentative is necessary so that students can establish a claim and use evidence and reasoning ability to support the claim that they submitted. The ability of students in an argument can be stimulated through a problem or a question that ultimately the students file a claim based on the data that they have and the reasons underlying the submission of the claim. Reasoning ability students can also be stimulated through the submission of an argument, because students must be able to connect the evidence that they have with the proposed claim. The process of linking evidence to the claim involves reasoning skills, so the more 
often students are stimulated to argue with reason and evidence is true, the more often students are trained to reason. Erduran et al. (2015) states that the argument has an important role in building explanations, models, and theories as well as scientists who use the argument to link the evidence they choose to claim that they have achieved through the use of warrants and backings[7].

\section{CONCLUSION}

Completeness of argument component son students who are trainedthe reasoning was better than students without training. Students who are given training was able gotreasoning training has been better than students withoutreasoning training. Students who are given training was able to achieve a higher level compare with students without reasoning training.

\section{Acknowledgement}

We are thankful to the teacher who participated in this study and to the Indonesia University of Education.

\section{References}

[1] Bekiroglu, F. O. \&Eskin, H. Examination of the Relationship Between Engagement in Scientific Argumentation and Conceptual Knowledge. International Journal of Science and Mathematics Education, 10, 14151443, 2012.

[2] Berland, L. K. \& Hammer, D. Framing for Scientific Argumentation. Journal of Research in Science Teaching, 2011.

[3] Berland, L.K., \& McNeill, K.L. Using A Learning Progression to Inform Scientific Argumentation in Talk and Writing. Learning Progression in Science, 2009.

[4] Brookhart, S.M. How to Assess Higher-order Thinking Skills in your Clasroom. Virginia: ASCD, 2010.

[5] Dawson, V. \&Venville, G. J. High-School Students' Informal Reasoning and Argumentation about Biotechnology: An indicator of scientific literacy?.International Journal of Science Education, 3 (11), 1421-1445, 2009.

[6] Duschl, R. A., \&Gitomer, D. H. Strategies and Challenges to Changing the Focus of Assessment and Instruction in Science Classrooms. Educational Assessment, 4(1), 37-73. 1997.

[7] Erduran, S.,Ozdem, Y., \& Park, J. Y. Research Trends on Argumentation in Science Education: A Journal Content Analysis From 1998 - 2014. International Journal of STEM Education, 2, 5, 2015.

[8] Fraenkel, J. R., Wallen, N. E. \& Hyun, H. H. How to design and evaluate research in education. New York: The McGraw-Hill Companies, Inc, 2012.

[9] Furtak, E. M., et al.A Framework ForAnalyzing Reasoning In Science Classroom Discourse. Paper presented at the Annual Meeting of the American Educational Research Association. New York, 2008.

[10] Herawati, Desti. Penalaran Ilmiah (Scientific Reasoning) Siswa Sekolah Berorientasi Lingkungan Dan Sekolah Multinasional. Bandung. Tesis: Universitas Pendidikan Indonesia, 2015.

[11] Hutapea, Nahor M, .Peningkatan kemampuan penalaran, komunikasi matematics dan kemandirian belajar siswa SMA melalui pembelajaran generatif. Tesis, SekolahPascasarjana, Universitas Pendidikan Indonesia, 2013.

[12] Inch, E. S., Warnick, B., \&Endres, D. Critical Thinking and Communication: The Use of Reason in Argument. USA: Pearson Education, Inc, 2006.

[13] Joko, S. Keefektifan model pembelajaran kontekstual dengan pendekatan open ended dalam aspek penalaran dan pemecahan masalah pada materi segitiga di kelas VII, 2012. [Online]

[14] Kuhn, D. \&Udell, W. The Development of Argument Skills. Child Development, 74 (5), 1245 - 1260, 2003.
[15] Kurniawati, R. Meningkatkan kemampuan berpikir kritis matematik siswa SMA melalui model pembelajaran missouri mathematics project: studi kuasi eksperimen terhadap siswa kelas X SMA N 11 Bandung, Skripsi, Universitas Pendidikan Indonesia, 2013.

[16] Kusumaningsih, Diah. Upaya meningkatkan kemampuan berpikir kritis siswa kelas X-C SMA N 11 Yogyakarta melalui pembelajaran matematika dengan pendekatan contextul teaching and learning (CTL) pada materi perbandingan trigonometri, 2011. [Online].

[17] Lee, C. Q., \& She, H. C.Facilitating Students' Conceptual Change and Scientific Reasoning Involving the Unit of Combustion. Research in Science Education, 40, 479-504, 2010.

[18] Mujiyanto. Pengaruh model blended learning terhadap pemahaman konsep ditinjau dari penalaran formal siswa kelas X SMA N 1 Balikpapan, 2012. [Online].

[19] Nichols, K., Gillies, R., \& Hedberg, J. Argumentation Based Collaborative Inquiry in Science Trough Representational Work: Impact on Primary Studemts' Represetational Fluency. Research in Science Education. DOI 10.10007/s1165-014-9456-4, 2015.

[20] Osborne, J., et al. Enhancing the quality of argument in school science. School Science Review. 83 (301), 2001.

[21] Roshayanti, F. Pengembangan Model Asesmen Argumentatif Untuk Mengukur Keterampilan Argumentasi Mahasiswa Pada Konsep Fisiologi Manusia. (Disertasi). Sekolah Pascasarjana, Universitas Pendidikan Indonesia, Bandung, 2012.

[22] Santrock, J. W. Educational Psychology 5th ed. New York: The McGraw-Hill Companies, Inc, 2011.

[23] Simosi, M. Using Toulmin's Framework for the Analysis of Everyday Argumentation: Some Methodological Considerations. Argumentation, 17,: 185-202, 2003.

[24] Tytler, R. et al.Constructiong Representations to Learn in Science. The Netherlands: Sense Publishers, 2013.

[25] Varma, K. Supporting Scientific Experimentation and Reasoning in Young Elementary School Students. Journal of Science Education and Technology, 23, 381-397, 2014.

[26] Verheij, B. Evaluating Arguments Based on Toulmin's Scheme. Argumentation, 19, 347-371, 2005.

[27] Waldrip, B., Prain, V., \&Sellings, P. Explaining Newton's laws of motion: using student reasoning through representations to develop conceptual understanding. Instructional Science, 41, 165 - 189, 2013.

[28] Yang, F.Y. \& Tsai, C.C. Reasoning about science-related uncertain issues and epistemological perspectives among children. Instructional Science, 38, 325-354, 2010. 